SHORT REPORT

\title{
Copies of clinic letters to the family
}

\author{
D G Bartle, L Diskin, F Finlay
}

Arch Dis Child 2004;89:1032-1033. doi: 10.1136/adc.2004.051938

In April 2004 guidelines were introduced advising that letters to the GP should be copied to parents of young people. A study was carried out to ascertain the views of young people and their parents as to who they felt should receive correspondence after an outpatient appointment.

$\mathrm{T}$ he NHS plan ${ }^{1}$ made a commitment that patients should receive a copy of clinicians' letters about them. The general principle is that all letters that help to improve a patient's understanding of their health and the care that they are receiving should be copied to them as of right. Where the patient is not legally responsible for their own care (for example, a young person, or child in care), letters should be copied to the person with legal responsibility, for example, a parent or guardian.

The purpose of this study was to ask young people and their parents:

(1) What format clinic letters should take

(2) To whom the letters should be sent

(3) At what age they thought young people should receive their own letters.

\section{METHODS}

A questionnaire was developed, approved by the local ethics committee and piloted. Two copies were sent to 100 consecutive families. The parents were asked to complete the first questionnaire and return it in the prepaid envelope, passing the second questionnaire to their son/daughter if they were happy for them to independently take part in the study. The questionnaire comprised three questions, with a number of options and space for free text.

- Question 1 focused on who the clinic letter should be primarily sent to and/or copied to

- Question 2 focused on which members of the family should receive letters

- Question 3 asked at what age young people should receive their own letters.

Families sent questionnaires were those attending outpatient clinics with children aged 11 years or older, where standard practice was to send correspondence to the GP only. These clinics included general paediatric, oncology, cardiology, and rheumatology clinics.

If a reply was not received after two months we sent a reminder questionnaire asking for this to be returned as soon as possible.

\section{RESULTS}

One hundred families were contacted. Seventy forms were returned from parents and 68 from young people; however, four were returned uncompleted from parents and five from adolescents. The eligible sample was $66 \%$ from parents and $63 \%$ from young people. The non-response rate was 30\% from parents and $32 \%$ from young people. The results are presented in table 1 and fig 1 .

Free text comments from parents included: "It should be up to (the parent) whether they give the letter to the child depending on the results or wording"; and from adolescents included: "The patient should be informed before the family and the letter should be addressed to him/her".

\section{DISCUSSION}

The Department of Health has produced clear guidelines for sharing letters with patients. Information is given on what constitutes a "letter", frequency of copies, "raw data", and it is clearly stated that letters should reflect the discussion in the consultation and should not contain any new information that might surprise or distress the patient. Guidance is also given on "when letters should not be copied", including where there are child protection or mental health problems, where the letter includes information about a third party who has not given consent, or where special safeguards for confidentiality may be needed. ${ }^{1}$

The views of parents and adolescents are explored in this paper and most parents and adolescents were in favour of receiving correspondence following an outpatient visit.

\section{Question 1}

Responses showed that for both groups the preferred option was for the letter to be written to the GP and copied to them, rather than written primarily to them and copied to the GP. A study from Nottingham also found that families preferred to receive the GP copy and accepted medical terminology knowing that they could ask for clarification. ${ }^{2}$ Although respondents in this study were not asked to comment on the reason for their choice possible explanations may be:

- It is what is being said between professionals that is important to families

- Concern that contents may be over simplified and some information excluded if the letter is written primarily to the family

- The concept of receiving correspondence may be so novel to our respondents that getting a copy of the GP letter was much more tangible than having a letter written specifically to them.

For young people, separate letters to the GP and family was a popular option. This may reflect concern regarding understanding the content of the letter.

Only $6.1 \%$ of parents and $7.9 \%$ of young people felt that letters should be sent to the GP alone. There are few other studies in the literature addressing this issue; one study by Cowper and Lenton ${ }^{3}$ found that $0 \%$ of parents were in favour of the letter being sent to the GP alone, in contrast to a study by Kenny and colleagues ${ }^{4}$ where only $33 \%$ of parents attending hospital clinics and $66 \%$ of parents attending a community clinic wanted a letter. 
Table 1 Results of the questionnaire; questions 1 and 2

\begin{tabular}{|c|c|c|c|c|}
\hline Letter option & Parent responses & $\%$ & $\begin{array}{l}\text { Adolescent } \\
\text { responses }\end{array}$ & $\%$ \\
\hline \multicolumn{5}{|c|}{$\begin{array}{l}\text { Question 1: Following an outpatient clinic the doctor } \\
\text { should write to: }\end{array}$} \\
\hline GP only & 4 & 6.1 & 5 & 7.9 \\
\hline GP + copy to family & 28 & 42.4 & 24 & 38.1 \\
\hline Family + copy to GP & 23 & 34.8 & 13 & 20.6 \\
\hline Separate letters to GP + family & 11 & 16.7 & 20 & 31.7 \\
\hline Other option & 0 & 0.0 & 1 & 1.6 \\
\hline Total & 66 & 100 & 63 & 99.9 \\
\hline \multicolumn{5}{|c|}{$\begin{array}{l}\text { Question 2: The doctor should write to the following } \\
\text { people in the family: }\end{array}$} \\
\hline Parent(s) only & 17 & 25.8 & 13 & 20.6 \\
\hline Child only & 0 & 0.0 & 7 & 11.1 \\
\hline Parent(s) + child, same letter & 36 & 54.5 & 30 & 47.6 \\
\hline Parent(s) + child, different letter & 13 & 19.7 & 13 & 20.6 \\
\hline Other & 0 & 0.0 & 0 & 0.0 \\
\hline Total & 66 & 100 & 63 & 99.9 \\
\hline
\end{tabular}

\section{Question 2}

The most popular option for both parents and children was a combined letter to them, and only a few wanted different letters to both parties. Twenty one per cent of young people thought that the letter should go to their parent only; a small number thought it should be sent only to them and not their parents.

\section{Question 3}

Responses varied widely from both parents and young people as to the age at which young people should receive their own correspondence. Young people generally wanted correspondence at a younger age than their parents felt appropriate. This may reflect the desire to exert some control over the way information is given to their children, or there may be a tendency to over protect children who have a long term medical condition. From a legal point of view a 16 year old is deemed competent to make decisions regarding their own health and should therefore be entitled to receive their own correspondence, but in many cases a younger person will show "competence as defined by Lord Fraser's guidelines" and may be entitled to receive letters directly. Professionals will need to establish two-way conversation with these young people to assess their ability to deal with the content of the letters. This may not be achievable in a single session and may require the professionals to offer the young people at least some consultation time without a parent being present. ${ }^{6}$

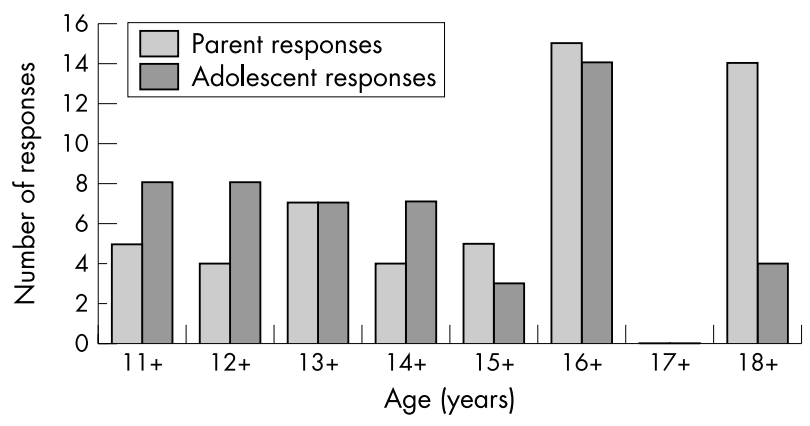

Figure 1 Question 3: At what age do you think children should receive their own correspondence?

\section{SUMMARY}

From the issues addressed in this study, it appears that:

- Most parents and young people want correspondence following outpatient appointments.

- Most people opted to receive a copy of the letter written between health professionals, although different opinions were expressed. It may well be that, in implementing this initiative, families will need to be given a choice as to the format of letter they receive.

- In terms of who should be receiving letters, most respondents were in favour of the same letter being sent to parents and young people, giving the opportunity to discuss content.

- Young people want copies of correspondence about them. Paediatricians should be working with parents and young people to empower young people to take more responsibility for their own health.

Further studies will be needed in future once parents start to receive correspondence, in order to obtain their views on the format and content of letters and to explore both the financial and time implications to health professionals.

\section{Authors' affiliations}

D G Bartle, F Finlay, Department of Child Health, Bath NHS House, Newbridge Hill, Bath, UK

L Diskin, Paediatric Department, Royal United Hospital, Bath, UK

Correspondence to: Dr D G Bartle, Department of Child Health, Bath NHS House, Newbridge Hill, Bath BA1 3QE, UK; dvdbartle@aol.com

Accepted 30 May 2004

\section{REFERENCES}

1 Department of Health. Good practice guidelines: Copying letters to patients, www. doh.gov.uk/patientletters/issues.htm.

2 Ali F, Charlton CPJ. Does copying letters to patients make for better education? Arch Dis Child 2004;89(suppl 1):A29.

3 Cowper DM, Lenton SW. Letter writing to parents following paediatric outpatient consultation: a survey of parent and GP views. Child Care Health Dev 1996:22:303-10.

4 Kenny JM, Vincent ML, Shabde N. Copy letters - do parents want them? Arch Dis Child 2004;89(suppl 1):A42.

5 Gillick v West Norfolk and Wisbech Area Health Authority [1985] 3 All ER 402 (HL). Parental rights endure only as long as they are needed for the child's protection.

6 Bull K. Copies of letters about children: areas of consensus and of potential conflict between professionals, parents and children, Department of Health, 2002.www.doh.gov.uk/patientletters/issues.htm. 